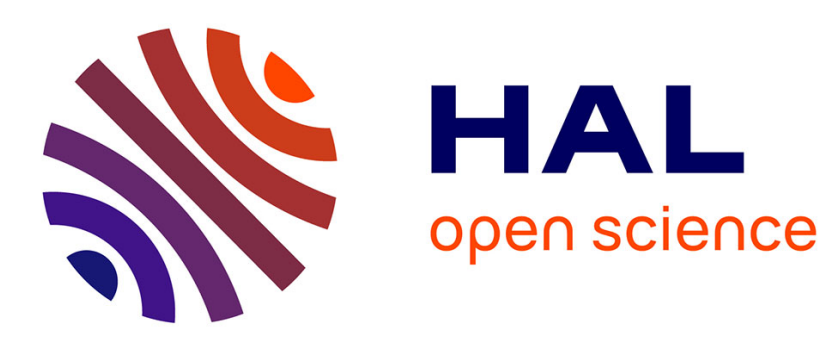

\title{
Representations of pesticides and social practices: the case of French farmers
}

\author{
Bouchra Zouhri, M. Feliot-Rippeault, Elisabeth Guillou, Weiss Karine
}

\section{To cite this version:}

Bouchra Zouhri, M. Feliot-Rippeault, Elisabeth Guillou, Weiss Karine. Representations of pesticides and social practices: the case of French farmers. Environmental Science and Pollution Research, 2016, 23 (1), pp.157 - 166. 10.1007/s11356-015-5055-9 . hal-01644887

\section{HAL Id: hal-01644887 \\ https://hal-amu.archives-ouvertes.fr/hal-01644887}

Submitted on 5 Apr 2018

HAL is a multi-disciplinary open access archive for the deposit and dissemination of scientific research documents, whether they are published or not. The documents may come from teaching and research institutions in France or abroad, or from public or private research centers.
L'archive ouverte pluridisciplinaire HAL, est destinée au dépôt et à la diffusion de documents scientifiques de niveau recherche, publiés ou non, émanant des établissements d'enseignement et de recherche français ou étrangers, des laboratoires publics ou privés.

\section{(이)(\$)}

Distributed under a Creative Commons Attribution - NonCommercial - NoDerivatives| 4.0 


\title{
Representations of pesticides and social practices: the case of French farmers
}

\author{
Bouchra Zouhri ${ }^{1}$ - ME. Feliot-Rippcanlt ${ }^{2}$ - E. Michet-Guillou ${ }^{3}$ - K. Weiss ${ }^{4}$
}

\begin{abstract}
Pesticides and their use iṇ agriculture are important social issues. We conducted research to study the construction of this sensitive social object through the lens of sociat reprcsentations (study of the structural organisation of the social representations of pesticides) and their anchoring in threc contcxts that differ in tems of famping practices (Martinique, Britany and Southern France). Our research was composed of two phases: hicrarchical associations $(n=213)$ and a context independence test questionnatre $(n=124)$, conducted among farmers from the three stidy stes. The results indieate three representational fields that reflect salient issues in each agricalural territory. These illustrate the heuristic nature of social representations in the analysis of agnicultural practices and pesticide use among Frcnch farners.
\end{abstract}

Keywords Sociai representation - Environmental and soctal psychology $\cdot$ Pesticte

Bouchra Zothri

bonchrazoutrigomines.fT

Laboratoire de Psychologie Sociale (EA 849), Université de Nimeg/ Aix-Marseille, Nìnes. France

I Grompe BIOSPHERES (EA 929), Universilé da Martinique, Martinique, France

3 Centre de recherche en psychologic, cognttion ct communteation (EA 1285), Université de Brelagnc, Bretagnc, France

4 Laboratoire Clarone (EA 7352), Univessité de Nînes, Nîmes, France
The use of phytosanitary products in France: from question to query

With 29 miltion ha of agricultural land and a tarnover of 96 billion euros from agricultural production, France is the leading agricultural country in the European Union. This leading role correlates to significant use of phytosanitary products (PP), which are essential for maximum yields. In relation to an on-going desire to increase farners' incone, these yields are PPs" reason to exist (Desbois and Legris 2003). Therefore, the initial causes of the rampant use of PPs should first be analysed in terms of "economic reasons" (Barbichon 1968). Tosay, the productivist agriculture inherited from such practices is in "crisis" (Deléage 2005) and often stigmatised (Roussary et al. 2013). Indeed, it raises issues in terns of cnvironmental (air, water and soil pollution), sanitary (public heatth) and professional (Dubuisson-Quellier 2009; Barrey and Kessous 2011) risks. The main aim of the Ecophyto plan. whitch was the starting point of our research, is to "reduce farmers' dependency on phytosanitary products while maintaining maximum yields, in quality and quantity" (Roussary et al. 2013, p. 68). This cannot be achieved without involving users of $\mathrm{PP}$ in the process of change. Hence, this study focuses on identifying such processes and obstacics of behaviour clange. In order to achieve a targeted communication with PP users and conceive innovative changes in practice, we must identify PP users? social representations of pesticides and the role they play in agriculural practices. Considering these issues from the perspective of the social sciences is an undeniable opening (Nichter 2008). 


\section{The pertinence of social representation theory}

This study is original in that it secks to integrate farmels as agents for change and hence no longer considers them only as spectators. This requires that we rely on "a community of practices that has shaped both ways of doing through multiple exchanges, and the concept of labour organised by a comnton pool of stories, chailcnges and experiences, gests, words and symbols" (Wenger 1999, p.27). Works by Nicourt and Girault (2011) should be noted, as they demonstrate the importance of involving winegrowers in change, and especially "attest to the benefits of endogenous collective action (...), appropriable mainly because it deftnes objectives on the basis of pect-to-peer dialogue" (Nicourt and Girault 201 1, p. 23). Therefore, instead of inposing injunctions whose consequences are contrary to the desired results, it is necessary to capture information and knowledge amongst the farmers thenselvos by studying thei social representation (SR) of pesticides. Social representations are defined as a type of social knowledge or "common sense" that is produced by "naīe" individuals, as opposed to "scientific klowledge" that is produced through logic (Moscovici 1961, p.54). Thus, social representations can be gualified as forms of collectively produced knowledge, which "contribute to the processes that guide belaviour" (Moscovici 1961, p.54). Better understanding of the social representations of pesticides antong farmers will hence allow us to identify elements upon which to basc a durable change in practice (Michel-Gujlou and Weiss 2007). As such, recent theoretical developments have highlighted the role played by social representations in connuibuent and conmitment contmunication. Indeed, several studies (Joule et al. 2007; Joule and Beatrois 2014) show that activating a central etement of a social representation through a conmitment act leads to more significant bchaviour change than activating a peripheral element. In other words, knowledge about the structure of the social representation of an object allows improving the efficiency of conmitment procedures and hence behaviour change (Solchet and Girandola 2013).

In retum, collective practices participale in structuring a group's SR (Flament 1987, 2001; Guinelli 1993; Guinclli et al. 1999). Consequently, the expected clrange in practice, which is a reduction of PP use, will necessarily impact the evolution of the SR of pesticides. Furthemnore, it is through different practices that groups distinglish themselves with tegard to the same object. Such otherness marks the identity of groups. Thus, for an individual to engage in one practice rather than another (adoption of biocontrol solutions, for example), it has to be coherent with his'her group's values and noms: "it's not ertough for an individual to be engaged in a practice for hirn/ her to recognisc it as his/her own and appropriate it. It also has to appear compatible with his/her value system" (Abric 1994, p. 220). This circular relationship beween representations and pretices clearly demonstrates the importance of apprehending representations both to better understand the associaled behavious that interest us and to better grasp the conditions of a possible cvolution integrating nornt and value systens that belong to the groups involved. Central core theory seens to provide a pertincnt framework to grasp the dynanics between social representations and social practices.

Initially, the structural approach to social representations hypothesiscd that they are each composed of central elements surrounded by other periplezal elements. Hence, to understand the operation and meaning of a social representation, one must deteraine not only its content but also its structure, that is to say, the (central or peripheral) status of the elements it contains. Here, a social representation is considered as a system containing two complementary components: a central system and a peripheral system. Each set of central or peripheral clements has a particular function within the representation. The peripheral system has a function of embodiment, regulation and protection, and the central system, a function of orgajisation and stabilisation. As such, structure necessarily means herarchy. Indeed, the integration of the central systen within the broader peripheral system implies not only inchsion characteristics but atso hierarchy. In other terns, individuals can attach different weights to each of the cognitions that make up thetr representation. Regarding the central core, we can list its functions, dimensions and its collective aspects. Indeed, it is "composed of one or more elements that give a representation its meaning", and hence detemines its organisation (Abric 1994, p. 19). Abric (1994) specifies that the central core is "the most stable elenent of a representation, and that it cnsures its sustainability in moving and evolving contexts" $(i b i d$, p.22). Flatnent (2001, p. 60) conmented on the intrinsic link of the central core to the peripheral system, the fomer giving meaning to the latter, "it is a system in which the central core is a structure in charge of the organisation of the rest of the system, that is to sny the perpheral elements". The contral system is hence considered as a sharce space for the group's memory: it is the product of historical, syntbolic and social deteminisms that a social group is submitted to (Moliner 1996, p. 61). Furthermore, a soctal representation is also composed of different elements that do not always have the same worth or the same sutability regarding the social norms that govern our society. Therefore, the "masking" of these clements can be qualificd as "denial", and refers to the existcnce of a "mute zone" of the representation (Guinclit 2003).

\section{Methodology}

\section{Sites of study}

This reserirch compares the SRs of famers in throe distinct agricultural territorics: Brithny, Martinigute and Soufhem France (the latter referring to the West of the PACA region and East of the Langiedoc-Roussillon). In not only geo-climatic but also cultuml tcms, these tentitories correspond to contrasted regions in France, 
with diffenent histories and agricultural practices. Indeed, different crops justify different clwices, especially in terns of PP use. The specific location of territories overseas could lighlight aspects linked to cultural differences in the apprehension of pesticide issues. However, Martinique was also chosen to ded? with a particular situation to do with Chlordecone, an organochlorinated insecticide used by banana growers for many years. In 2004, the risks related to the use of this pesticide were included in the National Healsh and Enviroment Plan (NHEP, action no. 12) and followed in Martinique by the Regional Phytosanitary Group (GREPHY). After having treated drinking water sources and organised preventive actions against the contamination of vegetables, the authorities wanted to structure their preventive action within the Chlordecone Plan. Thus, the environmental, sanitary and social consegutences of Chlordecone use were the object of sevend works: scicntific reports, epideniological sudies, reports by heaith agencies, new norms, and public prevertion and evaluation (INSERM 2009). However, these studies foctsed natinly on aspects of the sanitary crisis catsed by the use of this pesticide and on the health of indjuiduals directly aftected by it companed to the gencral population of the island (increasing risks of diabetes, cancer, nyelona, infertility, deformity, Alzheimer's, Parkinson's, etc.). Furthermorc, data on this PP remain underexplored oxtside of biological and chemical spheres. Thus, Martinique, which mainly grows bananas, is particularly marked by the Chlordecone scardal, which people still keep in mind.

The humid climate in Brittany complicates any cultures without the use of fungicides. Indeed, farning in this region is characterised by intensifying the production of livestock, fodder and vegetables. This preponderance of agriculture is linked to fragmented agricultural plots, which facilitate the transfer of pesticides to watercourses.

On the contrary, Southern Ftance is the region with the most organic farms. Thanks to cultures of grapevines, fruits and vegctables, Provencal agriculture is based mainly on plant products. Particularly it the PACA region, we find an inportant proportion of farners engaged in organic or reasoned practices; at the cnd of 2010, the PACA region was the leading French region in tems of organic farming. Thus, behind the term "agricultural territorics", we assemble these elemeats both according to the region and the territorial specificities in terns of agricultural practices. These three teritories were indeed chosen because of their local specificities regarding farming practices and hence pesticide use. Thus, the link between practices and representations cm be put to the test.

\section{Tools phase 1: hierarchical associations questionnaire}

\section{Ains of phase I}

The aim of this first stage of rosearch was to identify the contents of the social representation of pesticides among French farmers. The hierarchical associations questionnaire allows making assumptions abott the structure of the social representation of the studied object.

\section{Participants}

We questioned a sample of 213 French farners: 25 fenales and 188 males ( $M=40.43 ; \mathrm{SD}=1.86$ ). Sample details per tęritory are presented in Table 1.

\section{Procedure and data processing}

To access the social rempesentation of pesticides, we used a hierarchical associations questionnaire (Abric 1994; Moliner et al. 2002; Lo Monaco et al. 2008). Directy inspired by works by Vergè $(1992,1994)$, uhis method is pertinent in that it allows whe updating of implicit or latent elenenes that would be overcone or masked in discursive productions" (Abric 2001, p.63). It consists in asking each farmcr to associate to the tern "pesticide" the first five words or expressions that he/she spontaneously thinks of. Patticipants nutst then arrange their associations from (1) the least inportant to (5) the most importent. Thus, each item associated to the inductor pesticide benefits from an average valuc of importance in the representational field, as well as a mean frequency. Both of these indicators aflow us to hypothesise (Abric 2001) about the staus of the elements (i.e. central vs. peripheral): Potentially, central elements are both most frequent and most inportant. In addition, some objects are "sensitive" in that it is diffeult to takk about them spontancously: When an individual is asked to express his/herself about a social object, the listed elements can vary contextually (Guimelli and Deschamps 2000). Elsewhere, it has been slown (Weiss et al. 2006) that farmers do not easily tatk about certain aspects of their profession from fear of being judged neyatively. Thus, when questioned about the environment, they do not spontaneously mention issues of pollution, which can be associated to a stigmatisation of agricultural practices. Moreover, they refise any responsibility regarding their practices by operating sedf-serving social comparisons (Weiss et al. 2006), Here, we hypothesise that pesticides are such sersitive objects in that it is difficult to taik about then as a user. Indeed, they are socially stigmatised objects because they are associated to not only sanitary but also environmental risks, and nowadays, social noms favour the "environmentally friendly". In order to highlight these difficult-10-express elements, and hence potentially "Inasked" elements, "self-other substitution" allows individuals to express themselves in the name of a langer groupt here, "faumers in gencral". The aim of self-other suostitution is to "place the particjpant in a context that is distant from his/her teference group, and hence enabie him/her to express his/ her thoughts nore freely by reducing any risks of negative judgntent by others" (Abric 2005, p. 15), thereby revealing the mute zonc of the social representation. Therefore, we questioned farmsers ciller in a "standard" or a "substitutive" context in orter to obtain a broad nomenclature of the social tepresentation of 
Table 1 Sample of firmets questioned in phase 1 or the study "Hicrarc/ical associalions"

\begin{tabular}{lllll}
\hline & Organic faming & Conventionat armilor & Reasoned famaing & Total \\
\hline Southern Frunce & 30 & 6 & 14 & 50 \\
Britany & 10 & 92 & 25 & 127 \\
Martinique & 5 & 29 & 2 & 36 \\
\hline
\end{tabular}

pesticides in otr sanples. The coliected corpus was first lenmatised and hapaxes' were removed. Following this initiat "cleaning", we used the soltware Evoc 2000 to conduct lexicographical analysis on answers to the questionnaite. The main advantage of this sofware is its ability to bighlight wo criteria (i.c. frequency and rank) and hence hypothesise about the status of each clement. The hierarchical association technique only allows hypothessising about centrality. In the second phase, we conducted a context independence test (CIT) to validate or invalidate these centrality liypotheses.

\section{Tools phase 2: context independence test}

Aims of phase 2

The aim of this second phase was to validate the centrality hypotheses highlighted in phase I of this research. In other words, following the results obtained with the hicrarchical association questionnaire, wo administered a context independence guestionnaire to a different sanple in order to confirm the structure of the social representation of pesticides.

\section{Participants}

We questioned a sample of 124 French farmers: 20 females and 104 males $(M=40,43 ; \mathrm{SD}=1.83)$. Sample details per territory are presented in Table 2 .

\section{Procedure and data processing}

This test (CTF; Lo Monaco ot al. 2008) detennines the structumal status (central vs. peripheral) of the elements that cotstitute a representation and hence account for their respective importance.

The CIT is presented as a list of questions that focus on the independent or dependent characteristics of the studied items. For exarbple, "in your opinion, are pesticides always and in every case a sanitary risk?" Subjects answer the question on a scalc from 1 to 4 (no, not really, generally yes, yes; for statistical analysis, "no" and "not teally" scores were combined, is were "generally yes" and "ycs" scores). The plrasing "always and tn every case" operationalises the idea of cottext indepcndence. Thus, an affimative answer means that, in the eyes of the stibject, the relevant element is valid in all circumstances and constitutes a central element of the corresponding social representation. Once

\footnotetext{
A hapax is an answer with a frequency of 1 .
}

at answers were collected, we counted the number of positive answers per iten and then expressed these occurrences as percentages. Furthermote, we also calculated a $D_{\max }$ index for an error probability of 05 following Kolmogorov-Sminov's law as advised by Abric (2001). Calculating this index sets the threshold fron which an element can be considered central with respect to its percentage of occurcence.

\section{Hypotheses}

Given the highly sacial nature of the studied object (i.e. pesticides), mainly due to discourse and debates aroused by the media, we hypothesise that the social object pesticides pos. sesses all the necessary characteristics to be the object of a structured social representation. Morcover, given the role played by social practice and the environment in the structure of a social representation, we hypothesise that the structure will differ between the studied agriculural territories.

\section{Results}

\section{Centralify hypotheses}

A total of 1065 associations werc collected. Tab]es 3, 4 and 6 , present the elements that constitute the social representations of pesticides for eacl study site (i.e. Brittany, Southerr France and Martinique), obtained with the hieratehical association teclunique in two contexts (standard vs. substitution).

We present these associations according to the classification obtained with the softwate Evoc 2000, which offers fou structural stanses underlying the social representation of pesticides according to rank and frequency:

Potentially, contral elements are both frequent and highraking. ${ }^{2}$ that is to say, they are both mentioned and considered more important than the other clements.

. Potcntially, peripheral elcments are both infrequent and low-ranking, that is to say, they are mentioned less and considered less important than the other elements.

- The two ollier categories (contrasted elements and second periphery) correspond to elements whose frequency and

\footnotetext{
${ }^{2}$ Rank does not correspond to order of appearance, but to the rank attributed to each word by the subjects.
} 
Table 2 Sartiple of farmers questioned in phase 2 orthe sludy "Conlext ludependence Tesl"

Table 3 Classitication of associatious (Evoc 2000) for fanters in Southem France (frequency; rank)

\begin{tabular}{lllll}
\hline & Organic farning & Convertiontal farming & Reasoned farming & Total \\
\hline Southen France & 20 & 10 & 11 & 41 \\
Brittany & 0 & 27 & 14 & 41 \\
Martinique & 4 & 16 & 22 & 42 \\
\hline
\end{tabular}

\begin{tabular}{|c|c|c|}
\hline & Standard context & Substitutive contcxt \\
\hline Central elements & 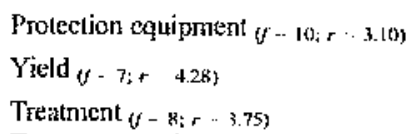 & Danger $(r-11, r-3.72)$ \\
\hline Peripheral elements & $\begin{array}{l}\text { Treatment prodticl } v-20: r-2.75) \\
\text { Environmentat risks } u \cdot 11 ; r \quad 275,\end{array}$ & 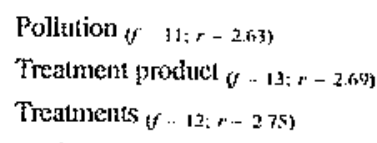 \\
\hline Second periplacry & 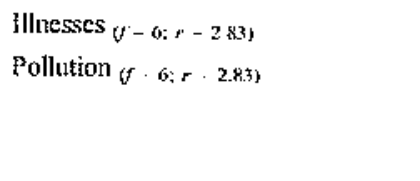 & 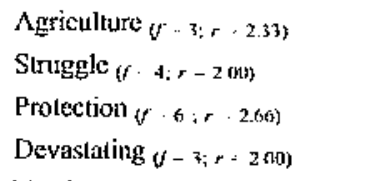 \\
\hline Contrasted elencuts & $\begin{array}{l}\text { Danger } y-6: r-3 \text { on } \\
\text { Grow a crop }(r-5 ;-.440\end{array}$ & 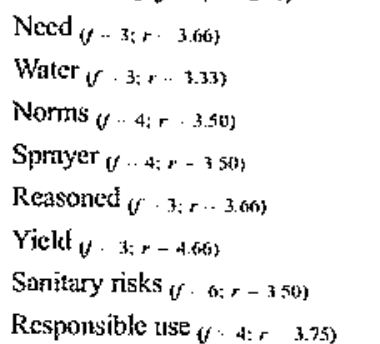 \\
\hline
\end{tabular}

rank are not congnent. They are either frequent or cot1sidered important, but not both at once. They wit] hence be tested in the same way as the central elements in the second phase, nantely the CIT.

This Table 3 clearly shows the differences between selfother substitution and the standard context. Indeed, the standard context rovealed no elements regarding risks in we central zone or first periphery. These appear in the second periphery (low frequency and importance), with the terms "pollution" and "illness", as well as biodiversity (bees) and other, more varied aspects. The notion of "danger" only appears as a contrasted element (low frequency and high importance).

On the contrary, the substitutive context revealed the term danger in the central zone. In fact, this was the only efement in that zonc. The first periphery supports this aspect, with the element pollttion atong with more technical aspects. Finally,

Table 4 Classilication of associations (Evoc 2000) for farners it Martinique

\begin{tabular}{|c|c|c|}
\hline & Standard coalext & Substitulive context \\
\hline Central elements & Nonns of use $(\mathrm{f}-9,-3.77)$ & Nomis of usc ${ }_{1}[-9, r-3.55)$ \\
\hline Prophctal elements & 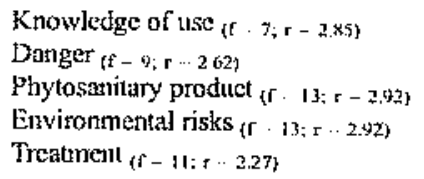 & 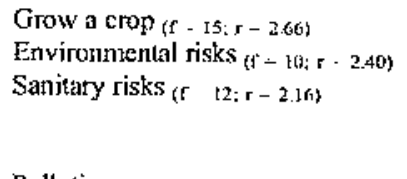 \\
\hline Second periphery & & 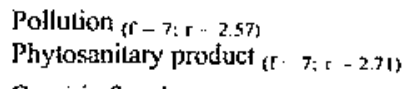 \\
\hline Contrasted elements & 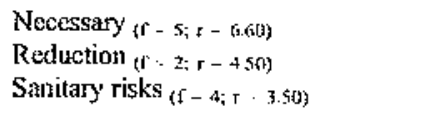 & 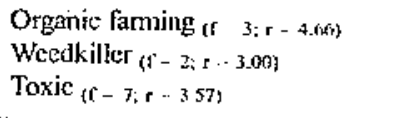 \\
\hline
\end{tabular}


Table 5 Classification of associations (Evoe 2000) for farmers in Britany

\begin{tabular}{|c|c|c|}
\hline & Standard cortext & Substitutive conlext \\
\hline Central clements & 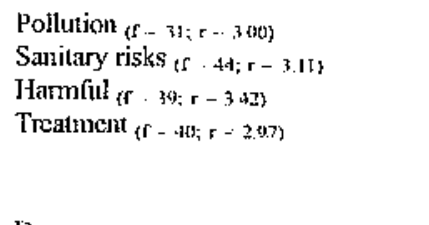 & 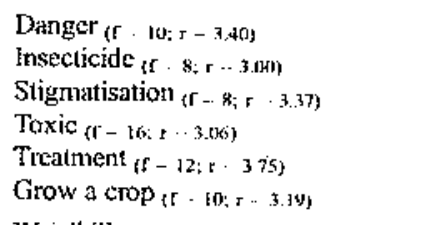 \\
\hline Peripheral elements & 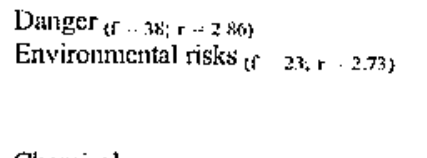 & 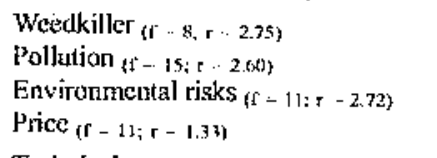 \\
\hline Sccotud periphery & 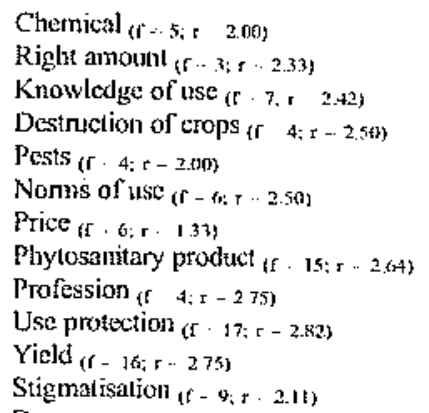 & 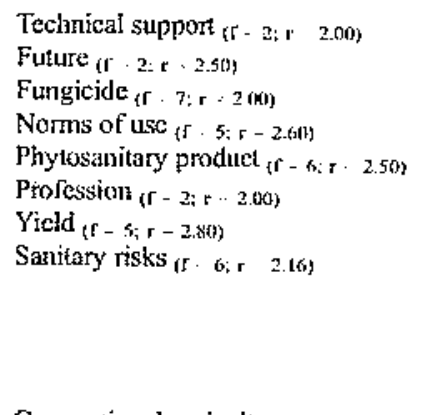 \\
\hline Contrastect elements & 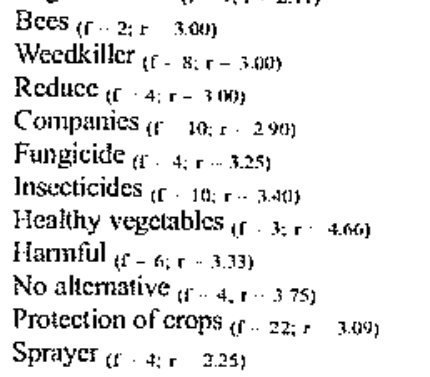 & 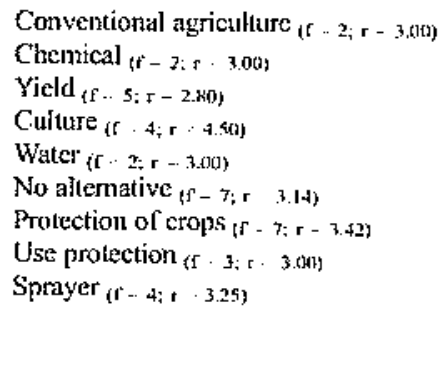 \\
\hline
\end{tabular}

both other zones are richer than in the standard context becanse elenents regarding the profession, envirommental aspects and the effective use of pesticides are nnore nunerous.

Here, in the Table 4, the central clement is the same no matter the context: noms of use. In the standard context, the first periphery contains items regarding the risks and tevel of knowledge in rotation to pesticide use. The contrasted elements are more varicd and span from the necessity to the reduction of pesticide uso. In the substitutive context, the first periphery is close to that of the standard contcxt, as it is also composed of items regarding the risks of pesticide use; however, it also contains a more definitional component ("grow a crop").

In the standand context (Table 5), the contral zotte contains negative elements. In Brittary, on the contrary, the notions of pollution, danger and risk are present. The central zone and first periphery contain itens that mostly refer to the dangers of pesticides. The other zones are very rich. Indeod, the second periphery refers to elcments directly linked to the profession and oconomic aspects (prices, yields), as well as to more technical aspects and consequences of use. The contrasted elements are more focused on emironmental aspects, such as crops, biodiversity (bees) and other, more varied aspects. In the substitutive context, the trom "stigmatisation of agriculture" appears in the central zone, along with aspects regarding the risks of pesticide use in the first periphery. Again, the second periphety refers to the profession and its fiture, as well as aspects to do with the use of pesticides,

All three tables confirm the relationship between agricultural territory and representation, which appears to be predominantly central. Thus, different practice-related representations cherge for each territory, hence distinguishing between the three groups studied. For cxample, the notions of "onvironmental risks" and danger only appcar as potentially central elements expressed by Breton farmers, whereas those from Martinique or Southen France are more focused on norms of use for the former and on the conditions for phytosanitary treatments for the latter. However, the three representations also share some items, because all three subsamples belong to a larger group of fanness who differ in tenms of the spccificities of their agricultural practices.

In order to verify the effective centrality of the elements obtained in this initial phase, the results must be confirmed by a context independenee test. 
Tabje 6 Comparison of $D_{\max }$ to the rate of "yes" answers for the elements submitted to the Crt for the item "pesticides" aunong farmers in Southem France

\begin{tabular}{lll}
\hline Associations & Rafe of "yes" answers in \% & Comparisols with $D_{\text {max }}=79.02$ \\
\hline Protective equjpment & 100 & $100>79.02$ \\
Environmental risks & 80.95 & $80.95>79.02$ \\
Responsiblc use & 100 & $100>79.02$ \\
Nonms of use & 100 & $100>79.02$ \\
\hline
\end{tabular}

Table 7 Comparison of $D_{\max }$ with the rate of "yes" answers for the elements subnjitted to the CIT for the item "pesticides" amolyg farmers iu Martinique

\begin{tabular}{lll}
\hline Assaciations & Rate of "ycs" answers in $\%$ & Comparison with $D_{\max } \times 79.02$ \\
\hline Namas of tsise & 95.23 & $95.23>79.02$ \\
Euvironmental risks & 88.09 & $88.09>79.02$ \\
Sanitary risks & 83.33 & $83.33>79.02$ \\
Toxic & 92.85 & $92.85>79.02$ \\
\hline
\end{tabular}

\section{Diatgnostic of centratity}

As a reminder, the substitution technique gives us access to tems that do not appear in the standari context. That being said, we proceeded with a centrality diagnostic on the set of itens with a CIT. In other words, for cach region and cach sample, we tested the potentially central and potertially peripheral itens, as wetl as certain elements that appeared contrasted. To achieve this, we administered a CIT questionnaire to famers from Brittany, Martinique and Southem France (Tables 6,7 and 8).

Tables 6,7 and 8 confinm that the social representations of pesticides differ between research sites, in the sense that the CIT validates the centrality of different elements for each territory. Given that these teritories deline different agricultural practices, these results also confirm a strong link between representations and practice. The CIT confinns the centrality of most of the potentially central elements from phase 1 , revealing the same lexical fields in each sample. Furthermore, the clement environmental risks appear central it all three representations.

\section{Discussion/conclusion}

These results reveal an impact of the "agricultural territory" variabie on the representation of pesticides. Therefore, they support our lypothesis that social practices related to pesticides are the key in the elaboration of social represcntations of pesticides. As noted by Abric (2001), a practical relationship, a high level of knowledge and betng involved are all factors that reduce distance to an object. The practicat relationship between farmers and pesticides enriches their knowledge about them. This demonstrates the importance of the peripheral elements of a social representation in guiding behavious with regard to an object. Thus, this process choes works by Flanent (I994a) who constiders social representations as organised systenss of deseriptive and prescriptive cognitions. According to the author, prescriptive cognttions refer to "procedural" knowledge.

Analysis of the results revealed three different representational structures between regions and hence three different social representations. Different "geo-cultural" anchors
Table 8 Comparison of $D_{\text {max }}$ with the rate of "yes" answers for tha clements submitted to the CIT for the jiem "pesticides" annotg farmers in Britany

\begin{tabular}{|c|c|c|}
\hline Associations & Rate of ${ }^{\text {tr }}$ yes" allswers in & Comparison with $D_{\mathrm{m} 1 \mathrm{x}}=78.76$ \\
\hline Savitary risks & 95.12 & $95.12>78.76$ \\
\hline Eiwitonmental fisks & 82.92 & $82.92>78.76$ \\
\hline Trealment produet & 80.48 & $80.48>78.76$ \\
\hline Experisive & 82.92 & $82.92>78.76$ \\
\hline Yield & 87.8 & $87.8>78.76$ \\
\hline Stigmatisation & 90.24 & $90.24>78.76$ \\
\hline I [arาnโfu] & 80.48 & $80.48>78.76$ \\
\hline
\end{tabular}


(Doise 1992,2005 ) can explain these results. Thus, the objoct pesticides has different meanings for farmers depending on their place of residence and practice (Martinique, Britany, Susthem France). These cultural anchors, or social roots, explain different stances regarding the object. This "type of approach constitutes a fertile path for analysing correspondences between social contexts and modes of social thought in the forming of a representation" (Dos Santos et al, 2011, p. 390).

In Southen France, where the use of pesticides is low, we observed a normative dimension referring to "responsible" discourse about pesticide use. Based on this observation, the representation is made of clements sucl as protective cquipment, norns of use and responsible use. This nomative discourse also contains the item environmental risks. In other terms, the social tepresentation of pesticides anong farners in Southern France is structured around central elements that refer to pablic authorities ${ }^{*}$ disconrse that is addressed to farmers, such as the idea that pesticides should be used responsibly with protective equipunant, respecting the terms of use, and being aware of any cnvirommental risks that pesticide use entails. This is a prescriptive function of social representations.

In Britany, where pesticide use is high, we observed a representation struclurcd aromd three dimensions: (1) risks and dangers related to pesticide use (including the items "sanitary risks", environmental risks and "hammful"), (2) the perception of farners by the population and (3) an economic dimension. These three dimensions inform us about different aspects of the social representation of pesticides in the Breton territory. As a stucturing elcment of the representation, the iten "stignatisation" helps to understand the anchoring of the social group "farmers" in the general population. Breton farmers are indeed ofter pointed at when it comes to sol and water pollution (Hellier et ai. 2013; Michel-Guilou 2011). This is another function of social representations, that is to say, the social expression of unhappiness (Jodelet 1989). The dimensions refering to (sanitary and environmental) risks indicate that Brcton farmers have integated the adverse consequences of pesticides into their social representation. The economic dintetsion is also fairly structuring in this sample: The ifem "treatment product" shoutd be considered as an cho of the term "expensive". In other words, the cconomic aspect of pesticides strongly contributes to structuring the social representation.

Lastly, in Marticique, where pesticide use is high, we observed a social representation structurcd around two dimensions: (1) risks and dangers related to pesticides and (2) the regulatory aspects of their use. It is as if knowledge about the risks is diminished by knowledge about the norms of use of phytosanitary products. Both dimensions are without doubt the result of poticies in the wake of the Chlordeconepolluted soit scandal in Martinique. This pesticide is particularly long lasting in the soil and as such, govermmental plans aim to put in place the necessary measures to accompany famers whilst also reinforcing local comununication to reassure famers and consumers. Because of this, farmers are highly monitored and have to follow traizing courses, particuiarly on the use of phytosanitary products. Furthermorc, nost respondents in the study work for sinall and medium farms that have been importantly changed over the last 20 years: They are more and more modem and professional and often offer diversified crops (livestock, vegetables, arboriculture, etc.). Indeed, Martinique seems more focused on a productivist view. This observation can be explained by famers' desire to reduce their economic vulnerability and their insular dependency, given that "useful spaces" for crops is linited and the economic context largely depends on the stock market and linding (Magnan 2009). Consequently, diversifying crops reduces these dependencies and favours a greater ability to adapt. This need to produce more henee explains the regular use of phytosanitary products. Keeping informed about the risks and regulations about pesticide use reassures famers and allows then to adapt to cconomic constraints and geographic specificities, as well as develop local resources, which are perceived as a source of community identity (Fomoa-Adenct and Rjeutor 2008).

Therefore, the study of sccial representations should avoid a simple description of dificrent representational strtichures so as not to fall, "as is often the case in tems of social representations, between triviality and originality" (Moliner et al. 2002, p. 202). Nonctheless, numctous clues for interpretation can be found in issues raised by the farmers' social context. Thus, farmers in Southern France do not include any dimensions regarding sanitary risks in their central elenents (nor in their peripheral etements), as opposed to both oher groups of farmets. This result is even more consistent when considered along with the other items diat structure the represcntation. It:deed, given that farmers in Southem France represent pesticides in terns of noms of use (cf. items regarding nonus of use, responsibie use, protective equipment), they logically and coherently do not integrate any itens in terns of sanitary risks. The group of fanmers in Southem Fance hence differs from Brelon and Martinique farmers, who express common dimenstons regarding pesticides. In particular, we observex the item sanitary tisks in both representational ficlds. Martinique has known important senitary issues with regatd to Chlordccone use. We stppose that the island's listory in relation to this sanitary scandal has impacted the crention of the social representation of pesticides antong Martinique fanners. The item sanitary risks is also present in the Breton conlext. These famers also use pesticides. They differ from Martinique because of their negative inage, becausc no itens in terms of protection or noms of use appear in the Breton representational fields, neither in the central elements, nor in the peripheral elements.

The representational structure highlighted in this study seems to reval a social state regarding pesticide issues in 
threc difierent contexts. These results illustrate the contribution of social representation theory to the study of pesticides as a socially constructed object, as a tolal social fact (Mauss 1973), or, as stated by Gauthter (2010), as a "controversial" object combining enough characteristics to evolve public discourse and, a fortiori, to be an object of representation. Within a context or culture, social representations allow the study of the interpretations of an object through "the enrolment of subjects in a social order and history" (Jodelet 2002, p. 129).

Fron1 a practical point of view, this social representation anatysis captures some of the issues related to pesticide use: Although the question of envitonmental tisks is presest in all three samples, it is not the case of sanitary risks, which calls into question pesticide use and precautions to be taken. Furthenzone, the discourse focuses on different elements: notms of use in one case (Southers France), toxicity in the second (Martinique) and more general issues in tems of agriculthral practices in the thitd (Brittany). These diferent ancions highlight specific preoccupations anong famers regarding their practice and use of pesticides. These aspects should be explored more precisely but already provide clues about the possibilities of better involving farmers in a more general discussion aboul changes in practice, and at the same tine integrating these inportant aspects in the praclice of their profession. Furthemore, considering social representations of pesticides from the point of vicw of lay hinking can account for a social reality that induces a rehabilitation of common sense (Nichter 2008). in other words, "this approach rehabilitates sucial thought to consider it cifferently than just a gan between scientific and sectsar knowledge" (Caillaud et al. 2010 , p. 626). Furthenore, as stated by Jusunio, "the astounding progress of science does not however reduce the sphere of coninon sense. On the contrary, the inevitable taylorization of scientific work leads to a reinforcenent of both fonms of knowledge we are all scientists just as we are all laypersons. This is presumably the situation that Jesuino had in mind when be stated that we bave entered the era of social Jepresentations" (2008, p. 394). Therefore, it is essential, when communicating about the risks of pesticide use, and more gencratly about the necessity to significantly reduce their use, to consider the "social system to prevent or adapt to crisis situations" (Specht 2008, p.46). Finally, the study of the social representations of pesticides amounts to the consideration of "socially shared worlds of interpretations in which objects are appropriated and legitimised in individual or soctal behaviours" (Dos Santos et al. 2011, p. 375).

Conflict of interest the authors declare that they have no confict of interest.

Funding This project is supported by the research program "Assessing und reducing environmental tisks from plant prolect ton produets" funded by the French Ministry in charge of Ecology and Agriculture.

\section{References}

Abric J-C (1994) Pratiques sociales et représentialions [Social practices and representationsl. PUF, Paris

Abric JC (2001) L'approehe stracharale des représentations socjales: developpements récents [The stuctural approach of soeial represelttations: recent developments]. Psychol Sociéte 4:60 104

Abric J-C (2005) A zola muda des representacoes sociais. ha Oliveira, D S. P. Campos. Representaçoes sociais, unja teoria sem fronleiras, Editora Museu da Republica. Rio de Jastejo, 34-56

Barbichon $\mathrm{G}$ ( 1968 ) Aspeets physiologiques et sociaux des transferts des agricutteuts de l'agriculture vers l'industric |Phystological and social aspeets of agricuture farmers transfer to indusuryl. Econonise Rurile 77

Barrey S, Kessous E (2011) Introduction. La consonmation à l'ère du dévcloppement dumbte: une ptutalite de logigues. Consonmer en protéger l'environtement. Opposition ou convergence ? [Introduction. Consumption in the era of sustainab]e developncht a plurality of logic. Consume and protect the environment. Opposition aud convergence ?] Paris. L'Hannatan. 13-21

Caillaud S, Kalampalikts N, Flick U (2010) Penser la crite toologique : representations el praliques franco-allcmandes [Titink or the ecological crisis: representations and French-German praptices]. Calsiers Int Psychof Soc 87:621-644

Delénge E (2005) L'agticulture durable : ulopic ou nécessité ? [Sustainable agriculture Ulopia or requires ]. Morvements 4l(4); 64.69

Desbois D, Legris B (2003) D'une réforme de ta potilique agricole communc à lautte. Baisse des prix et mâtrisc des coûts lOn the reform of the conmon agricultural policy to atiother. Lower pries and cost conltrol]. Premiere $927: 4$

Doise W (1992) L'ancrage dans les éudes sur les représentations sociales [Anchoring in the social representations sludies]. Bull Psychol 45: $189 \cdot 195$

Doise W (2005) Les representalions sociales [Social retresentation]. In: Dubpis N (cd) Psyehologie scciale de la cognition. Dunod, Paris, pp 152-207

Dos Santos $R+$ Apostolidis $T$, Santos MFS, Dany L (201I) Representations sociales el embryon humain ; une élude cenparalive Brósil / Fronce [Social representations and human embryo: a coniparalive sludy Brazil/ Francel. Cahiers tnt Psychol Soe 92:371 395

Dubuisson-Quelfier S (2009) La consonmation engagée [Engagod consumption]. Presses Universiaite de Science Po, 32-45

Fyssartier C, Joule R-V, Guimetli C (2007) Effels comportcmentiax et cognitifs de l'eugagenient dans un acte préparntoire activant un élément central versus périphérique de la représentation du don d'organes [Behavional and cognitive effects of the commitment in a proparalory act aetivating a centrat elenent versus pcriphteral of the representation of the organ donation]. Psychol Fr 52:499 517

flamen C (1987) Pratiques et représentations sociates [Social pracicos and representations]. In J. L. Beauveis, R. V. Joule, \& J. M. Monleil, Perspectives coggitives et conduilts sociales. 1:143-150, Cousset: Del vil

Fianeut C (1994) Aspects périphériques des teprésentations sociales [Pcripheral aspects of socjal representations], in: Guinelli C (cd) Structeres es transformations des représentations sociales. Delechaux et Niesté, Lausanne

Flament C (2001) Approche structurale et uspects normatifs des reprosentations soctales [Structural approach and nomplive aspects of social reprisentations ]. Psychol Société 4:57 80

Fomoa-Adenet M, Ricutort L (2008) Tertitoires rumaux insulaires et développenen durable [Instlat raral areas and sustainable developmern]. Etudes Caribéennes 11 
Gauttlice $E$ (2010) Social representations of risk in the food itradiation debate in Canada, 1986-2002. Sei Conmun 32(3):295 329

Guimelli C (1993) Concerming the Structure of Social Representations. Pap Soc Representations 2(2):85-92

Guimelli C (2003) Le modèle des selłènes cognilifs de base (SCB) : méthodes el applications [The model of basio cognitive schemes (SCB) : Methods and Applications]. II J.C. Abrie (Ed.). Mèthodes d'études des représentatious sociales, Saint Agne: Enss. 119-143

Gainetli C, Deschamps J-C (2000) Effels de contexte sur la production d'associations verbales. Le cas de la représentation sociale des Gitans [Context effects on the production of verbal associations. The case of the social representation of Gypsiesl. Cahiets Intenationaux de Psychologie Sociale, 47-48, 3-4/00, 44-5

Guinelli $C$, Reyuier J (1999) Structuration progressive d'une représentation sociaje: la représentation de l'infirmière PProgtessive structuring of a social representation : representation of thit nurse]+ In: Rouquette ML, Ganier C. (eds) La gencese des représcntations sociale. Editions Nouvelles, Montréal, pp 171 - I81

Fellier E, Miclzel-Guillos E, Dupont N, Coiftard M, Blane II (2013) Gestion durable de l'eat et enjeux. socio-teritoriaux lićs ì la ferneture de captages d'eat polable [Suslingable water management and secio- teritorial isstes related to the closure of diunking waler catchinents]. Analyse dans l'Ouest de la France. MEDDTL., 2e ARP Eaux el Jertiloires

INSERM (2009) Impacl Sanitaire de l'uttisisation du chlordécone atix Antitles françaises: Reconnandations pour les recherehes et ies actions de santó publique.

Jesuino JC (2008) Conceptualizing Sacial Psychology. Rassegna di Psicol Quad Speciale 2-2008:4 1-49

Jodelet D (1989) Folies et representations sociafes [Follies and sociai reptesentations?. PUF, Paris

jodelet D (2002) Les represenlations socjales dars ic chanm de la culture [Secial representations in the rield of culture]. info Sei Socides $4 !(1): 111 \cdot 133$

Joute RV, Beauvois J-L (2014) Petii Irailé de manipulation b̀ l'usage des Ironetcs gens [Small frealy of maniptation for the honest people]. Grenoble, PUG

Joule RV, Girandola F, Benard F (2007) How ena people be indeed to willingly chatnge their belavior? The path lion persuasive communicstion to binding communicalion. Soc Personal Psyciol Compass

Lo Monaco G, Lheureux F, Halimi-Falkowicz S (2008) Lee test d'intépendance au contexte (TIC): tne nouwelle technique d'élude de la structure representationnelle [The independence test context (ITC): is new feclanique for studying the representational stucture]. Swiss J Psychol 67(2):119-123

Magnar A (2009) Systènes insulaires, représentiations pyranidales et soutenabilite : approche comparative codan Indien/Petites Anliles [island systems pyranidal representations and sustainability : Indiat Ocean compartitive approach / Antilles]. Les Cahiers d'Ontrc-Mer $248529-548$
Manss M (1973) Essai sur le don: forme el raison de l"échange dans les sociẹtés archaîques [The Gift Form and beanse of the cxelange in archaic societies]. In Sociologic et Anthropologie, PUl', Collection Quadrige, 149-279

Michcl-Guillow E (20fl) La construction sociale de la sessource en eau ['The social constuction of water resources]. Prat Psychol 17:219. 236

Michcl-Guiltou $\mathrm{E}_{\text {; }}$ Wesss $\mathrm{K}$ (2007) Represcmations and behaviors of farmers with regard to sustainable development: a psychoenvironmental approach. Ta: Larson BA (ed) Sustainable Development Reseatch Advances. Nova Science Publeshers. IJaupparge, $N Y$, pp 207:-221

Molint P (1996) İnages el représenlations sociales [lmage and sociai representation ]. Presses Universitaires de Grenoble, Grenoble

Molinter P. Ratcau P, Colıen-Scili V (2002) Les représculations sociales. Pratigue des éludes de terain [Social repriscotations. Pretical field studics]. PUR, Rerrits

Moscovici S (1965) La psychanalyse, son image, son public [Psychoanalysis, its imnige, ils public]. PUF, Paris

Nichter M (2008) Global Heath: why cultural perecption, social representations, and biopolftics matter

Nicourt C, Gitalt J-M (2011) La normalisation de travai] viticole a ['épreuve de la réduction de l'usage des pestitides [The staldardization work of the wine to the test of reducing the use of pesticides]. Economic numle, 321

Roussary A, Busca D, Dumont A, Carpy-Goulard F, Salles D (2013) Pratiques phylesanitaires en agriculture cl environnement : des tensions iméduetbles? [Phylosanitary practices in agricutture and environment: jreducible tensions]. Éconornie nurale, 336-337

Souchel L, Girandoia F (2013) Double bot-in-the-doot, social represenbations, ind enviroument: application for bergy savirgs. J $\Lambda$ ppl Soc Psychol 43(2):306-315

Speclu I (2008) Mental beałty in schools; tessons letned from exciusion. Con J Sclool Psyclool (4):43-55

Vergès $P(1992)$ L'évocation de l'argent: une métlode pour la défintition du noyau central d'une representations [The evosition of money : nethod for defining the eore of a represctitarion]. Bult Psychol 405 $203 \cdots 209$

Verges $P$ (1994) Approche du noyau central: propriẹtés qualiatives et structurales, słruetures el transformations des représentations sociales [Approach to the core : quatitalive and structural properties, structures and transformations of social represenations]. In: Guinet $C$ (ed) Structures et transfornations des représchations sociales. Delachaux \& Niestić, Neuchatel, pp 233-254

Weiss K, Moser G, Gennanı C (2006) Pesception de l'cnvironnentent, conceptions du mélier et platiques culturales des itgriculicurs dats lo cadre du développeneout dirable IPesceptions of the environment, designs the ant and culturat practices of farnters in the context of sustainable development]]. Rev Eur Psyelool Appl 5673-81

Wenger $E$ (1999) Conyunities of praclic: leaning, meaning, and identjty. Cambridge University Press, Cambridge, pp 234 245 